\title{
The Effect of Job Characteristics to Employee's Performance: A Case Study on Employees at Interior Industry
}

\author{
S.H. Senen *, M. Masharyono, N. Edisa \\ Universitas Pendidikan Indonesia \\ Bandung, Indonesia \\ *masharyono@upi.edu
}

\begin{abstract}
Every organization is trying to achieve their goals. Factors to improve the development and progress of the company cannot be separated from the role of human resources that move the organization within the company. Employee performance is still an important problem in manufacturing companies, especially in CV. Saputra Jaya in Cimahi. One of the company's efforts to improve employee performance is by improving the understanding of the characteristics of an employee's job. The present study uses descriptive analysis technique and verificative. As for the design, the study uses a cross-sectional design, while for the method uses an explanatory survey. The study used 75 respondents who have been selected by using non-probability sampling. A questionnaire was used as a research instrument to collect the data from respondents. The analytical technique used is a simple linear analysis technique. Based on the results of the study using a simple linear regression analysis, there is a positive influence between job characteristics on employee performance. The present study provides a basis for understanding the issues of job characteristics on employee performance. The difference between the present study and the previous one is on the objects, variables, theories, and references used by the writer.
\end{abstract}

Keywords-Job Characteristic; Employee's Performance; Human Resources

\section{INTRODUCTION}

The organization is kind of places for two or more people who work together achieve common goals. Organizations are groups of people who work interdependently on multiple goals [1] to reduce organizational effectiveness [2]. Organizational behavior is a field of study that investigates the impact of individuals, groups, and structures on behavior within organizations, with the aim of applying such knowledge to improve organizational effectiveness [2]. The role of organizational behavior (PO) is recognized as a competitive advantage in organizations [3]. An organization of both companies and government agencies in carrying out its activities certainly require human resources that support efforts to achieve the goals set by the organization [4].

Human resources are the best asset for a country or any organization. Humans play an important role in every life and are critical to the performance of an organization such as administration, manufacturing, production or service. Thus, it is important for the economy of any country. [5]. Without human roles, factors, tools and even the material the company needs is available, an organization will not work [6]. The existence of human beings as human resources is very important in the organization because human resources support the organization through talent, creativity, encouragement and the actual role that can be seen in every organization. [7]. Each organization is required to keep its employees in order to show a good performance and maintain their employees in order to dedicate themselves to the organization in the work field. [8]. Companies can develop because of the human resources as an activator so that it will make the company more advance [9].

Organizations that have human resources with high responsibility, high morale, reliable law, it is certain that the organization will have a good performance [10]. The quality of employee achievement can be seen from its performance and every employee's performance is important in the organization [11]

The issue of employee performance is a concern. Research on the low level of employee performance has been widely done from 2000 until now (21st century). Problems that concern to the low employment occur in several areas, ranging from the Hospital [12], Banking [13], Marketing [14], Government [15], Health [16], Agriculture [17], Emergency services [18] Academic [19], and Insurance [20] The manufacturing industry has also been one of the many precedents in the past [6].

Companies that engaged in the manufacturing sector is a company that engaged in the production sector. It is based on the efficiency and effectiveness of employees [9]. Therefore, companies that engaged in the manufacturing sector rely on the quality and performance of high employees. There are many studies that examine the issues regarding employee performance within the company including manufacturing industry sectors in various countries such as in Nigeria [6], Iran [21], India [22] and many others. Based on a study by [22], it reveals that the manufacturing sector in India is one of the engines that create a development for India. Unfortunately, this sector has not been able to overcome the challenge of poor performance for years

Problems regarding employee performance also occur in Indonesia. There is a study in manufacturing field that states that there are data on the performance of the employees who 
Job characteristics helps to facilitate employees in the have not reached the target. The results of a study conducted by [23] suggest that the performance of employees in sales division at UD Surya Raditya from July to October 2013 has not been realized optimally. This can be seen from the fluctuating sales levels and it has not been fully achieved.

Lack of employee performance has a significant impact on companies or organizations. The low employee performance also has a relationship with various factors. [24], [19], [25] suggests about the factors that affect the performance of employees are consisting of 1) Job stress, 2) Job Characteristics, 3) Role conflict, 4) Motivation, 5) Social support, others mention about factors related to employee performance 6) Work environment 7) Leadership 8) Job satisfaction [26], [27].

Job characteristics determine the appropriateness of people with a particular field of work and enable people to be more successful in the field. The understanding of the job characteristics, it is expected that the employee will be more oriented in the field. It is important for a company to pay attention to the quality of human resources [28]. Employees will pursue the work with concentration and responsibility in the accompaniment of happiness to get a satisfactory result. If an employee has characteristics that match with the job, then the performance will increase [29]. Various studies have been conducted to examine the relationship between job characteristics and employee performance [30], [31], [32], [33].

Based on the background of the above problem, the purpose of this study is to obtain findings on: (1) an overview of job characteristics, (2) an overview of employee performance, and (3) the impact of job characteristics on employee performance.

\section{LITERATURE REVIEW}

Organizational Behavior is a study that studies the three determinants of behavior in the organization, namely individuals, groups and structural effects on behavior to make the organization work more effectively [34]. Organizational behavior plays an important role in determining the productivity and performance of employees that will impact the company.

When an employee understands the characteristics of the job, then an employee will make every effort to accomplish the tasks very well. The existence of human beings as human resources is very important in the organization because human resources support organization through talent, creativity, encouragement and the role that can be seen in every organization [7]. Job characteristic is greatly determining the actions of employees. According to [35], job characteristics, psychological critical condition, and individual work results are the basis of job design for employees related to job satisfaction issues, employee motivation and employee performance.

According to [34], Job Characteristics is an effort to identify the characteristic tasks, how they are combined to form different jobs and their relationship to motivation, job satisfaction and performance. work field that give a good impact to the company. When employees can fully understand job characteristic, they learn an easier way to get things done and maximize their skill.

According to Richard Hackman and Greg Oldham who have been developed by [35]. The dimension of job characteristics is divided into:

1 Skill variation, it is the degree to which a job covers a variety of different activities and involves the use of a number of different skills and talents.

2 The task's identity, it is to which the work requires the completion of an "entire" and recognizable work, which involves doing the work from start to finish with visible results

3 Autonomy, it is the extent to which the job gives freedom, independence, and discretion to the employees in scheduling the work and determining the procedures used to the implementation.

4 Job feedback, it is to which the implementation of job activities provide direct and clear information to employees about how well the work has been done.

There are dimensions of job characteristics according to [36] the dimensions as follows:

1 Skill Variety: The degree to which the job has many different activities that uses someone's skills, abilities, and talents.

2 Task identity: The degree to which the job allows a person to do all parts of the job from start to finish.

3 Task significance:To what extent which the person doing a job perceives as important to others in the organization or client of the organization.

4 Autonomy: The level people's wisdom in deciding how and when to do the job.

5 Feedback: to what extent do the work activities produce a direct and clear information about the effectiveness of performance.

Performance is a process of how work takes to achieve results but the work itself also shows performance [37]. The organization can operate because of the activities that are undertaken by employees. Employee performance includes three dimensions, such as productivity, quality of work, and job achievements [38].

According to [39], there are three main factors that affect employee performance, these factors are: Individual ability to do the work, Effort expended, Organizational support.

Bernardin and Russell in [10] suggest six primary performance that can be used to measure performance, it is as follows:

1 Quantity, it is the extent to which the process or outcome of the implementation of activities or tasks are given near perfection or near the expected goal. 
questionnaire distribution, and literature study. Meanwhile, the technique of data analysis is descriptive and verificative analysis. Analysis of verivicative data is using simple linear regression analysis with SPSS 22.0 for windows.

\section{RESUltS AND DISCUSSION}

coted a predetermined time, taking into account the coordination of other outputs and the time available for the activities of others

4 Cost effectiveness, is to what extent do the use of organizational resources (such as human, financial, technological and material) is maximized to achieve the highest result or reduction of losses from each unit of the resources.

5 Need for supervision, it is to what extent does a worker can perform a job function without requiring supervision to prevent undesirable actions.

6 Interpersonal impact, it is to what extent do the employees maintain self-esteem, reputation, and cooperation among their co-workers and subordinates.

Based on the explanation about the effect of job characteristics on the employee performance, the study arranged a paradigm of the influence of job characteristics on employee performance that is clearly described in Figure 1. as follows:

\begin{tabular}{|l|}
\multicolumn{1}{c|}{ JOB } \\
CHARACTERISTICS \\
1) Skill variety \\
2) Task identity \\
3) Task significance \\
4) Autonomy \\
5) Feedback \\
\end{tabular}

\begin{tabular}{|ll|}
\hline \multicolumn{2}{|c|}{ EMPLOYEE } \\
PERFORMANCE \\
1) Job quality \\
2) Job quantity \\
3) Schedule \\
4) Cost Effectiveness \\
5) The Needs of \\
Supervision \\
6) Interpersonal impact \\
\hline
\end{tabular}

Figure 1. Research paradigm.

\section{METHODOLOGY}

This study was conducted to determine the effect of job characteristics on employee performance. The independent variables found in this research are job characteristics with various skill dimension, task identity, task significance, autonomy, feedback. Additionally, the study uses the dependent variable. It is the employee performance with the dimensions of work quality, a quantity of work, schedule, cost-effectiveness, monitoring needs and interpersonal impact.

The object / the unit of analysis in this study is CV Saputra Jaya Cimahi. This study was conducted in less than one year, so that the data collection technique used in this research is cross-sectional method. The technique used in this research is a probability sampling technique with 75 employees. Data collection techniques used were field study with direct

\section{A. Descriptive analysis}

\section{1) Job characteristic}

A good job provides an opportunity for employees to utilize their skills in practicing knowledge of known employee jobs and assigning responsibility for employees to complete their tasks until finish. Job characteristics are as a measured by the ability to complete the job, the diversity of skills, and feedback. This shows that employees in carrying out their work are required to have a good ability, adequate skills in carrying out work widely and complex, and on the items of work arrangements of employees in carrying out the work is in accordance with the instructions and orders of the superior [33].

Table 1. Recapitulation of job characteristic variables.

\begin{tabular}{lllll}
\hline No & Dimension & Score Total & Ideal Score & $\%$ \\
\hline 1 & Skill variety & 2313 & 2625 & 88 \\
2 & Task identity & 1816 & 2100 & 86 \\
3 & Task significance & 2267 & 2625 & 86 \\
4 & Autonomy & 2290 & 2625 & 87 \\
5 & Feedback & 1784 & 2100 & 85 \\
& Total & 10470 & 12075 & 86 \\
\hline
\end{tabular}

Based on Table 1 on the results of the research from questionnaires that are distributed to 75 respondents, it can be seen that job characteristics in CV Saputra Jaya reached a 10470 score from the criterion score or the maximum number. Obtaining the value of respondents lies in the area of good criterium that is at intervals 9330 to 10701 . The highest score is in the range skill dimension with score 2313 or $88 \%$ of the ideal score. The statement items are given to the respondent and the response to the variety skill dimension indicating that the employee is satisfied because the employee has various skills appropriate to his / her job. The employee's knowledge of individual differences determines whether the characteristics of the core work will actually trigger a critical psychological state. This difference is the knowledge and skills of the workers. A worker must have the knowledge and skills that is required to do the job successfully; this is as it has been expressed by model Hackman-Oldham in [40].

Meanwhile, the lowest dimension is on the dimensions of Feedback that get a score of 1784 or $85 \%$ from ideal score. The job characteristic affects the job's result, this is because, with good characteristics, the employees affect the three state of employees associated with the progress of the company. The five main job characteristics consisting of various skills, task identity, task responsibilities, autonomy and feedback affect the extent to which employees experience three critical psychological states, or personal internal reactions to their job [40]. 
maintain them to dedicate themselves to the organization in the work field. [7].

[41] suggests that performance as the real behavior that every person shows as a job achievement generated by employees in accordance with its role in the company. Employee performance becomes very important in the company's efforts to achieve its goals and become one of the main factors of successfull company. Based on the results of data processing conducted through questionnaires on employees in $\mathrm{CV}$ Saputra Jaya, employees can be measured through the calculation of the average dimensions and calculation of the overall score. The following table shows the results of the recapitulation of the calculation's score:

Table 2. Recapitulation of employee performance variables.

\begin{tabular}{lllll}
\hline No Dimension & $\begin{array}{l}\text { Total } \\
\text { Score }\end{array}$ & $\begin{array}{l}\text { Ideal } \\
\text { Score }\end{array}$ & \% \\
\hline Employee performance & & & \\
\hline 1. Job quality & 1768 & 2100 & $84 \%$ \\
2. Job quantity & 1330 & 1575 & $84 \%$ \\
3. $\quad$ Schedule & 915 & 1050 & $87 \%$ \\
4. Cost Effectiveness & 2195 & 2625 & $84 \%$ \\
5. $\quad$ The Needs of & 1760 & 2100 & $84 \%$ \\
& Supervision & & & \\
$6 . \quad$ Interpersonal impact & 1723 & 2100 & $82 \%$ \\
\hline \multicolumn{7}{l}{ Total } & $\mathbf{9 6 9 1}$ & $\mathbf{1 1 5 5 0}$ & $\mathbf{8 3 \%}$ \\
\hline
\end{tabular}

Based on the results of the study from a questionnaire that has been distributed to 75 respondents, it can be seen that the employee's performance on CV Saputra Jaya reached 9691 scores from the criterion score or the maximum number. The value of respondents lies in areas of high criterium that is at intervals 8720 to 10134 . The highest score is on the timeliness dimension with a score of 915 or equal to $87 \%$ of the ideal score.

The case shows that most employees can do the task punctually. In manufacturing companies, a punctuality of targets according to customer demand is a very important role to increase customer confidence in the future. Performance is a person's result at work in performing the job based on the schedule and targets that have been determined so that the company's objectives can be accomplished and achieved, it can be stated that the employees have a good performance [29].

Meanwhile, the lowest score is in the interpersonal impact dimension which scored 1723 or $82 \%$ of the ideal score. In the interpersonal impact dimension, there is a communication that must be woven by colleagues to facilitate the work and avoid obstacles from any misscommunication matters. Good communication and directional communication is one key to fostering a good working relationship. Similarly, poor communication can lead to misunderstandings because of failure to express opinions and aspirations among employees. A good communication network can be used as a tool to provide work motivation and foster a good teamwork. (Wulandari et al. 2015). Every organization is required to keep the employees are able to show good performance and

\section{B. Verivicative analysis}

To test whether there is any independent influence on the dependent variable, it is done by simple regression testing. Model of simple regression equation which will be formed in the study assisted by using SPSS 22.0 for windows, the result of regression coefficient is as follows.

Table 3 Simple linear regression model on job characteristics of work performance.

\section{Coefficients $^{\mathrm{a}}$}

\begin{tabular}{|c|c|c|c|c|c|c|}
\hline \multirow[b]{3}{*}{ Mode } & & \multicolumn{5}{|c|}{ UnstandardizedStandardized } \\
\hline & & Coeffi & cients & Coefficients & & \\
\hline & & B & $\begin{array}{l}\text { Std. } \\
\text { Error }\end{array}$ & Beta & $\mathrm{t}$ & Sig. \\
\hline$\overline{1}$ & (Constant) & 9.050 & 10.710 & & 0.845 & 0.401 \\
\hline & $\begin{array}{l}\text { Characteristic } \\
\text { Job }\end{array}$ & $\mathrm{c}_{0.861}$ & 0.076 & 0.797 & 11.260 & 0.000 \\
\hline
\end{tabular}

Based on Table 4 in column B, there are constant values and simple linear regression coefficients for independent variables. Based on the values, it can be determined a simple linear regression model expressed in terms of equations as follows:

$\mathrm{Y}=\mathrm{a}+\mathrm{bX}$

$\mathrm{Y}=9.050+0.861 \mathrm{X}$

Based on the simple linear regression equation above, the constant value of 9.050 states that if there is no job characteristics, then the employee performance is 9.050 . Regression coefficient on work characteristic variable is 0.861 which means that every additonal value of job characteristic will improve on employee performance which is about 0.861 . Conversely, if there is a decrease in employee performance, job characteristics will decrease the employee performance which about 0.861 of unit value. It can be said that the characteristics of work in the organization will have a positive effect on employee performance level. If job characteristics are not good, then employee performance will be low.

Determination coefficient analysis is used to determine the percentage of influence that occurs from the independent variable to the dependent variable. Based on the results of data processing, there are results obtained in Table 5.

Table 4 Coefficient of determination of job characteristics on employee performance.

Model Summary

\begin{tabular}{lllll}
\hline Model & $\mathrm{R}$ & R Square & $\begin{array}{l}\text { Adjusted } \\
\text { Square }\end{array}$ & $\begin{array}{c}\text { RStd. Error of } \\
\text { the Estimate }\end{array}$ \\
\hline 1 & $0.797^{\text {a }}$ & 0.635 & 0.630 & 7.819 \\
a. Predictors: (Constant), Job characteristic & \\
\hline
\end{tabular}


The calculation result of coefficient of determination $\mathrm{X}$ to $\mathrm{Y}$ is described as follows:

$$
\begin{aligned}
& \text { KD }=r^{2} \times 100 \% \\
& =r^{2} \times 100 \% \\
& =(0.797)^{2} \times 100 \% \\
& =0.6724 \times 100 \% \\
& =63.52 \%
\end{aligned}
$$

The calculation result of determination coefficient for job characteristics $(\mathrm{X})$ on employee performance $(\mathrm{Y})$ is about $63.52 \%$. In other words, employee performance influenced by $63.52 \%$ of job characteristic, while $36.48 \%$ influenced by factors that does not examined in the study such as compensation, leadership and work environment [42].

\section{Simultaneous hypothesis testing (F test)}

Meanwhile, to test the significance of job characteristics that affect employee performance can use F test, which is by comparing between $\mathrm{F}$ count and $\mathrm{F}$ table. The test formula $\mathrm{F}$ or ANOVA test is described in Table 6 as follows.

Table 5. Value of significance of $F$ test on job characteristics on employee performance.

\section{ANOVA ${ }^{\mathrm{a}}$}

\begin{tabular}{lllllll}
\hline Model & \multicolumn{2}{l}{ Sum } & of & Mean & & \\
Squares & df & Square & F & Sig. \\
\hline 1 & Regression & 7751.599 & 1 & 7751.599 & 126.791 & $.000^{\mathrm{b}}$ \\
& Residual & 4462.988 & 73 & 61.137 & & \\
\multicolumn{1}{l}{ Total } & 12214.587 & 74 & & &
\end{tabular}

a. Dependent Variable: Employee performance

b. Predictors: (Constant), Job Characteristics

Table 6 shows the $\mathrm{F}$ test taken from Anova with the probability level of $(\mathrm{Sig})=0.000$, then the 0.05 significant level is $0.000>0.05$ so that Ho is rejected. This means that there is influence of job characteristics on employee performance in CV Saputra Jaya Cimahi.

The writer also conducted a testing of independent variables with the dependent variable at the same time by using the $\mathrm{F}$ test that is Fcount $\geq \mathrm{F}$ tabel. Then, Ftabel with 75 respondents is at $\mathrm{a}=0.05$ is 1.80 . So that obtained $63.52 \geq 1.80$, which means that $\mathrm{Ha}$ is accepted. The conclusion is the same as the test performed by using probability values. It can be concluded that the hypothesis in this study shows that Ho is rejected and $\mathrm{Ha}$ is accepted. Therefore, there is influence between job characteristics on employee performance in $\mathrm{CV}$ Saputra Jaya Cimahi. This is supported by a study from Hacman and Oldham (Frismandiri 2007) which states the factors that affect employee performance is the job characteristics.

A study by [43] identifies factors affecting job performance, which include organizational structure, which comprises centralization and formalization, and job characteristics. The results conducted by [44] on the influence of job characteristics on employee performance indicates that job characteristics affect employee performance and show that if the task is well implemented, it will improve the real behavior that is shown in every person as a work achievement. Meanwhile, the result study by [45] shows that job characteristics are the basis for productivity and employee job satisfaction that designed to play an important role in the company's success and survival. Then, [46] study shows that job characteristic is important at the individual level because each dimension has a strong influence on the attitudes and behavior. Theoretically, this study provides additional empirical evidence in the theoretical domain of job characteristics. This can be a useful basis for increasing employee involvement of government employees and job performance.

Based on the above statement, the writer assumes that job characteristics have an impact on employee performance, where if job characteristics are well understood, then the employees performance will increase. The implications of the work characteristic model indicate that when the strength of growth needs meets the characteristics of the job, it will achieve high performance and job satisfaction Hackman and Oldman [32] Therefore, companies need to give an understanding of job characteristics so that employees contribute maximaly, complete the task well, and also provide good performance optimally to achieve organizational goals in the company.

\section{CONCLUSION}

Based on the results study that has been done by using descriptive and verificative analysis and by using simple linear regression analysis techniques, it can be concluded that job characteristics have a positive effect on employee performance.

The study is expected to assist the next researcher in conducting research on job characteristics and employee performance by using different indicators from more diverse theoretical sources, and to different objects, because there are many limitations in this research, especially those who relate to research methods and data collection techniques.

\section{REFERENCES}

[1] McShane, S. L. \& Glinow, M.A.V. 2010. Organizational Behaviour. New York: McGraw-Hill/Irwin

[2] Robbins, S.P. \& A.Judge, T. 2015. Perilaku Organisasi (16th Ed.). Jakarta: Salemba Empat.

[3] Memari, H., Valikhani, M., Aghababaee, Z. \& Davali, M.M. 2013. The effect of positive organizational behavior of the staff on organizational performance, based on the luthans model in public organizations of Behbahan. Interdisciplinary Journal of Contemporary Research In Business 4(9): 568-583.

[4] Dedi, D., Ulyadi, U., Eman, S. \& Aries, R. 2012. Pengaruh budaya organisasi terhadap kinerja pegawai pada dinas bina marga dan pengairan Kabupaten Karawang 09(4): 944-954.

[5] Ahmad, A., Hussain, A., Saleem, M.Q., Asif, M., Qureshi, M., \& Mufti, N.A. 2015. Workplace stress : A critical insight of causes, effects and interventions 20(Ii): 45-55. 
[26] Abdul, R.A., Jaafar, M., Abdullah, S. \& Muhammad, S. 2009. Work environment factors and job performance: The construction project manager's perspective. Ibadan, Oyo State, Nigeria. International Journal of Arts and Commerce 2(2): $27-32$

[7] Masharyono, M. \& Senen, S.H. 2015. analisis job performance pegawai honorer administrasi dengan kompetensi dan job characteristics dalam mendukung universitas pendidikan indonesia mencapai leading and outstanding. fokus ekonomi 10(2): 119-137.

[8] Masharyono, M. 2017. Pengaruh job characteristic terhadap semangat kerja pegawai 863-880.

[9] Wahyuni, Y. \& Senen, S.H. 2016. Pengaruh gaya kepemimpinan dan budaya organisasi terhadap kinerja karyawan PT Sugih Instrumendo Abadi di Padalarang. Journal of Business Management Education 1(2): 59-69.

[10] Sutrisno, E. 2013. Budaya Organisasi. Jakarta: Prenadamedia.

[11] Wei, L.T. \& Yazdanifard, R. 2014. The impact of Positive Reinforcement on Employees' Performance in Organizations. American Journal of Industrial and Business Management 4(1): 9.

[12] Ekawati, R. \& Prasetyo, A.D. 2017. The effects of internal corporate social responsibility on employee performance through organizational commitment in hospitality industry. International Conference on Tourism Gastronomy and Tourist Destination 28(Ictgtd 2016): 188-191.

[13] Chijioke, N., Chinedu, F., Egbunike, E. \& Chinedu, F. 2015. Effect of rewards on employee performance in organizations : A study of selected commercial banks in Awka Metropolis 7(4): 80-89.

[14] Ravinarayana, R. \& Ramakrishna, R. 2016. Impact of job stress on employee's performance: An emperical study, 11(1): 2016.

[15] Takasenseran, M.C., Mandey, S.L. \& Kojo, C. 2014. Pengaruh lingkungan kerja, komunikasi dan stres kerja terhadap kinerja pegawai pada Dinas Pendidikan dan Kebudayaan Provinsi Sulut. Jurn 2(3); 1726-1736

[16] Arbabisarjou, A., Ajdari, Z., Omeidi, K. \& Razieh, J. 2013. The relationship between job stress and performance among the hospitals nurses. World of Science Journal 02: 181-188

[17] Khaleghi, A., Najafabadi, M.O. \& Lashgarara, F. 2015. Effective factors on job stress from experts' perception: A case study in Iranian agriculture engineering organization 5(1): 94-99.

[18] Sahiwal, S.R. 2014. Impact of job stress on consumer satisfaction with role of mediating variables (Employee satisfaction and employee performance ): A study of punjab emergency. Journal of Asian Business Strategy 4(5): 58-73.

[19] Ali, W.U., Raheem, A.R., Nawaz, A. \& Imamuddin, K. 2014. Impact of stress on job performance: An empirical study of the employees of private sector universities of Karachi, Pakistan. Research Journal of Management Sciences 3(7): 14-17.

[20] Djauhari, D. \& Rachmansyah, Y. 2010. Strategi meningkatkan kinerja penjualan asuransi jiwa (studi di ajb bumiputera 1912 kantor cabang Semarang). Prestasi 6(01)

[21] Mehdi, S., Davoudi, M. \& Allahyari, M. 2013. Effect of Job Organization on Job Performance among Operating Staffs in Manufacturing Companies: 136-139.

[22] Mathews, C. \& Khann, I.K. 2016. Impact of work environment on performance of employees in manufacturing sector in India : Literature review. International Journal of Science and Research (IJSR) 5(4): 2013-2016.

[23] Dewi, C.N.C., Bagia, I.W. \& Susila, G.P.A.J. 2014. Pengaruh stres kerja dan kepuasan kerja terhadap kinerja karyawan pada bagian tenaga penjualan UD Surya Raditya Negara. E-Journal Bisma Universitas Pendidikan Ganesha 2(2).

[24] Ahmed, A. \& Ramzan, M. 2013. Effects of job stress on employees job performance: A study on banking sector of Pakistan. IOSR Journal of Business and Management 11(6): 61-68.

[25] Ling, S.AI.M.E.I. 2014. An investigation on factors of work stress influence job performance: Moderating by social support master of science Universiti Utara Malaysia, (May).

[27] Widodo, D.S. 2014. Influence of leadership and work environment to job satisfaction and impact to employee performance (Study on industrial manufacture In West Java). Journal of Economics and Sustainable Development 5(26): 2010-2015.

[28] Senen, S.H. \& Solihat, S. 2008. Pengaruh motivasi kerja dan kemampuan kerja karyawan terhadap produktivitas kerja karyawan pada PT.Safilind Permata. Jurnal Pendidikan Manajemen Bisnis 7: 1-15.

[29] Nursafitri, I., Prihatini, D. \& Krisnhabudi, N.G. 2015. Pengaruh karakteristik pekerjaan dan stres kerja terhadap kinerja karyawan melalui kepuasan kerja (Studi pada karyawan bagian produksi perusahaan Rokok Gagak Hitam Bondowoso). Artikel Ilmiah Mahasiswa: 1-5.

[30] Kassem, H.S. \& Sarhan, A.M. 2013. Effect of job characteristics on satisfaction and performance: A test in Egyptian agricultural extension system. African Journal of Agricultural Research 8(48): 6126-6130.

[31] Lubis, Y. 2012. Pengaruh karakteristik individu, karakteristik pekerjaan, iklim organisasi terhadap kepuasan dan kinerja karyawan. Trikonomika 11(2): 212-228

[32] Frismandiri, D. 2007. Analisis pengaruh karakteristik pekerjaan, kepuasan kerja, dan komitmen terhadap kinerja karyawan. Jurnal Ekonomi Modernisasi 3(2): 114-134.

[33] Heriyawan, M.S. \& Setyowati, W. 2013. Pengaruh karakteristik pekerjaan dan pemberdayaan terhadap kinerja pegawai dengan mediasi komitmen organisasional: $978-979$.

[34] Robbins, S. \& Judge, J. 2015. Organizations Behavior. New Jersey: Pearson.

[35] John R.S.J., G.Hunt, J., Osborn, R.N. \& Uhl-Bien, M. 2010. Organizational Behaviour. United States: John Wiley \& Sons. Inc.

[36] Amstrong, J.C. 2016. Organization Behaviour (15th Ed.). New York.

[37] Wibowo, W. 2014. Manajemen Kinerja (4th Ed.). Jakarta: Raja Grafindo Persada.

[38] Aktar, S., Sachu, M. \& Ali, M. 2012. The impact of rewards on employee performance in commercial banks of Bangladesh: An empirical study. IOSR Journal of Business and Management 6(2): 9-15.

[39] Robert, L.M. \& Jackson, J.H. 2010. Human Resource Management (13th Ed.). South-Western: Cengage Learning.

[40] Wagner, J.A. \& Hollenbeck, J.R. 2010. Organizational Behaviour. New York: Routledgge.

[41] Veithzal, R.E.J.S. 2014. Manajemen sumber daya manusia untuk perusahaan: dari teori ke praktik. Rajawali Pers.

[42] Y, I.N.Y.D. \& Mujiati, N.W. 2016. Pengaruh kompensasi, kepemimpinan dan lingkungan kerja terhadap kinerja karyawan pada hotel Griya Santrian. E-Journal Manajemen Unud 5(4) 2369-2395.

[43] Khin, E.W.S., Seeramulu, T., Muhamad, R., Nazri, M \& Yeap, L. wee. 2017. CSR organisational taxonomy and job characteristics on performance : SME case studies. Audit Fananciar 2(2): 230-243.

[44] Affandy, R.E. 2016. Pengaruh karakteristik pekerjaan terhadap kinerja pegawai dengan motivasi dan lingkungan kerja sebagai varibel pemoderasi. Ekonomika- Bisnis 07(02): 77-86.

[45] Chandra, L., Mulyanto, J.C. \& Nugroho, A. 2014) Analisa Pengaruh karakteristik pekerjaan terhadap kepuasan dan kinerja karyawan di hotel D'season Surabaya. Jurnal Hospitaly Dan Manajemen Jasa 2(2): 312325.

[46] Johari, J. \& Yahya, K.K. 2016. Job characteristics, work involvement, and job performance of public servants. European Journal of Training and Development 40(7): 554-575. 